
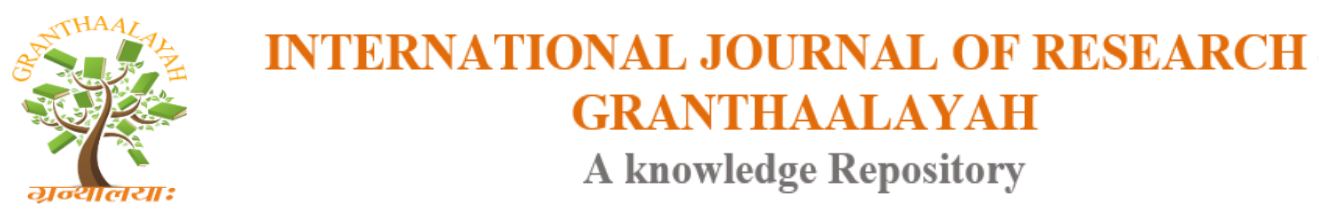

\title{
Social
}

\section{SOCIAL CAPITAL CLASSIFICATION OF SEAWEED CULTIVATORS (CASE STUDY IN LIYA MAWI VILLAGE, SOUTH WANGI-WANGI DISTRICT IN WAKATOBI REGENCY, INDONESIA)}

\author{
Ine Fausayana *1, La Nalefo ${ }^{1}$, Samsul Alam Fika ${ }^{1}$, Dian Aris Ani ${ }^{1}$ \\ ${ }^{1}$ Department of Agribusiness, Faculty of Agriculture, Halu Oleo University, Kendari, Southeast \\ Sulawesi, Indonesia
}

\begin{abstract}
Social capital plays a vital role in a business as so does in seaweed cultivation. The aims of this study are to know the social capital of cultivators and to analyze the relation of social capital toward business successfulness of seaweed cultivators in Liya Mawi village. The variable of the study is social capital, such as trust, network, and norm; and business achievement based on sales volume and income. This study used the descriptive analysis and correlation test with rank spearman correlation test. The result of this study showed that the social capital of seaweed cultivators in Liya Mawi village are in the medium category to high at around $44.68 \%$ have medium level of trust and $55.32 \%$ have a high trust level and there is no respondents who have a level of low trust category; Networking category is as high as $42.55 \%$ and $57.45 \%$, and there are no farmers are included in the category of low network; and the level of compliance with the norm being as much as $23.40 \%$ and a high level of norms compliance as much as $76.60 \%$, while for the low category does not exist. The results of data analysis showed that social capital has a relationship with the level of success of the venture, while the views of the elements of social capital, only the network level that has a relationship with the level of business successfulness.
\end{abstract}

Keywords: Trust; Network; Norm; Selling and Income.

Cite This Article: Ine Fausayana, La Nalefo, Samsul Alam Fika, and Dian Aris Ani. (2018). "SOCIAL CAPITAL CLASSIFICATION OF SEAWEED CULTIVATORS (CASE STUDY IN LIYA MAWI VILLAGE, SOUTH WANGI-WANGI DISTRICT IN WAKATOBI REGENCY, INDONESIA)." International Journal of Research - Granthaalayah, 6(6), 101-108. https://doi.org/10.29121/granthaalayah.v6.i6.2018.1341.

\section{Introduction}

Social capital is the ability of people to work together for a common goal in the various groups and organizations (Coleman, 1999). There are three elements, components, resources and important element in a social capital: trust, values and norms and networks (Fukuyama, 1996; Bourdieu, 1986; Putnam, 1993). 
The results of the previous research on social capital have been carried out. Fausayana (2015), argued that social capital is different for each group or ethnic of seaweed farmers depend on habit, economic and cultural habit of farmers and each ethnic group has a social capital against the risks that will occur (Fausayana et al, 2017). Social capital emphasizes the potential of individuals and groups in social networks, norms, values, and trust among members of a group that was created and became the norm of the group.

Social capital can be a determining factor in technology adoption. Research by Mathijs (2003) pointed out that farmers are more open to professional and non-contact to professionals are more likely to adopt a Countryside Stewardship Schemes (CSS). Therefore, the government and the extension agencies should take more effort to involve farmers as much as possible in professional activities and /or non-professionals to induce them to adopt sustainable farming practices. This is in accordance opinions of Limon et al (2013), that social capital has proven to be a key factor in explaining the development process.

Social capital is correlated to educational background and has a clear effect on farmers' income. The effect of farmer's interaction toward education showed that people with education and social capital will have a much higher income than the farmers without the relevant education (Hansen and Greve, 2015). Social capital also affects the economic development of developing countries (Hoyman et al, 2016). The study of social capital is also carried out by Ville et al (2016), which presents the results of an exploratory study of how various forms of social capital that is embedded in a community-based social networks can affect innovation in small-scale farming systems in supporting food security in the Caribbean. Study conducted by Sharp and Smith (2003), showed that agricultural support and tolerance will be stronger when farmers and non-farmers strengthen their social capital.

\section{Research Methods}

\subsection{Location and Time of Study}

This study was conducted in Liya Mawi village, Wangi-Wangi District, Wakatobi on May-June 2017. The research location is determined based on the consideration of seaweed cultivation in Liya Mawi village which has grown rapidly with the largest number of cultivators as many as 89 people (53.29\%) of the total of 167 farmers in South Wangi-Wangi Regency.

\subsection{Population and Sample}

The population in this study amounted to 89 people. Samples in this study are taken by using purposive sampling method. Sample size is determined by using Slovin formula (Setiawan, 2007) so that obtained samples of 47 seaweed farmers.

\subsection{Types, Data Sources, and Data Collection Techniques}

The type of data in this study is divided into two, namely qualitative and quantitative data. Data sources are primary and secondary data. Data collection is done through observation, in-depth interview and documentation. 


\subsection{Data analysis}

In addition to quantitative data analysis, qualitative data is also used as supporting data. The conclusion of the research results is carried out by taking the results of the analysis between consistent variables. Qualitative data will be processed through three stages, those are data reduction, data presentation and conclusion (Sitorus 1998).

\section{Results And Discussion}

The social capital of seaweed farmers in Liya Mawi Village studied in this research includes Level of Trust, Network, and Norm.

\subsection{Level of Trust}

Fukuyama (2001) divines trust as an attitude of mutual trust in a society that allows them to unite with each other and contribute to the enhancement of social capital. Aspects of trust becomes a major component of social capital formation in rural areas, while other aspects (cooperation and networking), will not be formed properly if it is not based on the mutual trust between members of society, especially the business community. Seaweed cultivators classification based on the level of trust in this study are presented in Table 1.

Table 1: Classification of Seaweed Cultivators by Level of Trust

\begin{tabular}{|l|l|l|l|}
\hline \multirow{2}{*}{ Number } & \multirow{2}{*}{ Level of Trust } & \multicolumn{2}{|c|}{ Number of Cultivators } \\
\cline { 3 - 4 } & & Number (Sample) & Percentage (\%) \\
\hline 1 & Low & - & - \\
\hline 2 & Medium & 21 & 44,68 \\
\hline 3 & High & 26 & 55,32 \\
\hline Total & & 47 & 100,00 \\
\hline
\end{tabular}

Based on the data in Table 1, the trust levels of seaweed farmers in Liya Mawi Village are 21 farmers $(44.68 \%)$ have a Medium level of trust and 26 farmers $(55,32 \%)$ have high trust and there is no respondent having low trust. This shows that seaweed farmers in Liya Mawi Village trust each other and have a good cooperative relationship.

The level of trust is not only established between seaweed farmers, but also to seed suppliers. This form of trust can be seen from the tendency of seaweed farmers to select and use seeds at the same supplier for long periods of time and are reluctant to move to other suppliers. They believe that the price given by suppliers is relatively cheap and affordable.

On the other hand, the trust between seaweed farmers and buyers is shown by the quality of seaweed sold. They believe that seaweed which is sold to consumers has good quality. This proves that buyers have trust in the quality of the seaweed they get from the cultivators. In addition, the belief of seaweed cultivation is also intertwined with related agencies including the government. They respond positively to counseling in extending their knowledge toward seaweed management. 


\subsection{Network}

Social Capital is a new additional variable in modeling the growth that represents the form of trust and social networks on productivity which causing the growth. In other words, it means that social capital is one of the variables that drive economic growth through trust and social networks (Lopez et.al, 2012).

Seaweed cultivators classification based on cooperation or a network connection in this study are presented in Table 2.

Table 2: Classification of Seaweed Cultivators by Level of Network

\begin{tabular}{|l|l|l|l|}
\hline \multirow{2}{*}{ Nu } & Level of Network & \multicolumn{2}{|c|}{ Number of Cultivators } \\
\cline { 3 - 4 } & & Number (Sample) & Percentage (\%) \\
\hline 1 & Low & - & - \\
\hline 2 & Medium & 20 & 42,55 \\
\hline 3 & High & 27 & 57,45 \\
\hline \multicolumn{2}{|l|}{ Total } & 47 & 100,00 \\
\hline
\end{tabular}

The data in Table 2 shows that the competence of seaweed farmers mostly has medium and high network category. Medium network category was 20 farmers $(42,55 \%)$ and high as 27 farmers $(57,45 \%)$ and there were no cultivators belonging to low network category. This means that the cultivators of seaweed in Liya Mawi Village have an extensive network. The network formed by seaweed farmers is based on the principle of mutual trust which then cooperates with various parties.

High network level started by a lot of interactions among farmers, either in the village or with other villages. This opportunity is used to exchange information about seaweed, both management and treatment of disease seaweed. Cultivators also know many buyers from various regions. The number of known buyers becomes a guarantee for cultivators in terms of marketing the crops. The good relationship between cultivators and buyers has long established and there are even cultivators who have memorized the names of buyers and where they are from.

\subsection{Norm}

Norm is a special identity that is capable of forming social capital. Norms are a code for individual behavior and what they should do. In addition, the norm is a means of preserving the integrity and existence of a particular community. A society is called having a high existence if they have valid norms and mutually agreed.

Table 3: Classification of Seaweed Cultivators by Level of Norm

\begin{tabular}{|l|l|l|l|}
\hline \multirow{2}{*}{ Number } & \multirow{2}{*}{ Level of Norm } & \multicolumn{2}{|c|}{ Number of Cultivators } \\
\cline { 3 - 4 } & & Number (Sample) & Percentage (\%) \\
\hline 1 & Low & - & - \\
\hline 2 & Medium & 11 & 23,40 \\
\hline 3 & High & 36 & 76,60 \\
\hline Total & 47 & 100,00 \\
\hline
\end{tabular}


Based on the data in Table 3, seaweed farmers' obedience level in Liya Mawi was pretty good with the level of compliance to norms were as many as 11 people $(23.40 \%)$ and a high level to norms obedience as many as 36 people (76.60\%), while the low category does not exist. This means that the observance of the norms applied by seaweed farmers is high, both in society and government laws and regulations.

Rules that applied to seaweed farmers is not written but created and decided by mutual agreement. There are some rules agreed by the farmers, those are: the determination of standard price of seaweed, the determination of area and boundaries under cultivation, and the determination of the minimum wage for workers.

Minimum wage for workers also agreed together in accordance with the work charged. Commonly workers are given a wage USD 0.36 / rope ( $25 \mathrm{~m}$ long). Determination of wages is influenced by the price of seaweed. If the price of seaweed rises, then the wage of labor will also be raised by the farmers. Beside determining the price and wages, the distribution and mapping of the area of cultivation are also mutually agreed together. Each farmer has their own areas in accordance with the customary law and trusted by the local community.

In detail, the comparison of Social Capital of Seaweed Cultivators in Liya Mawi Village can be seen in the following figure 1.

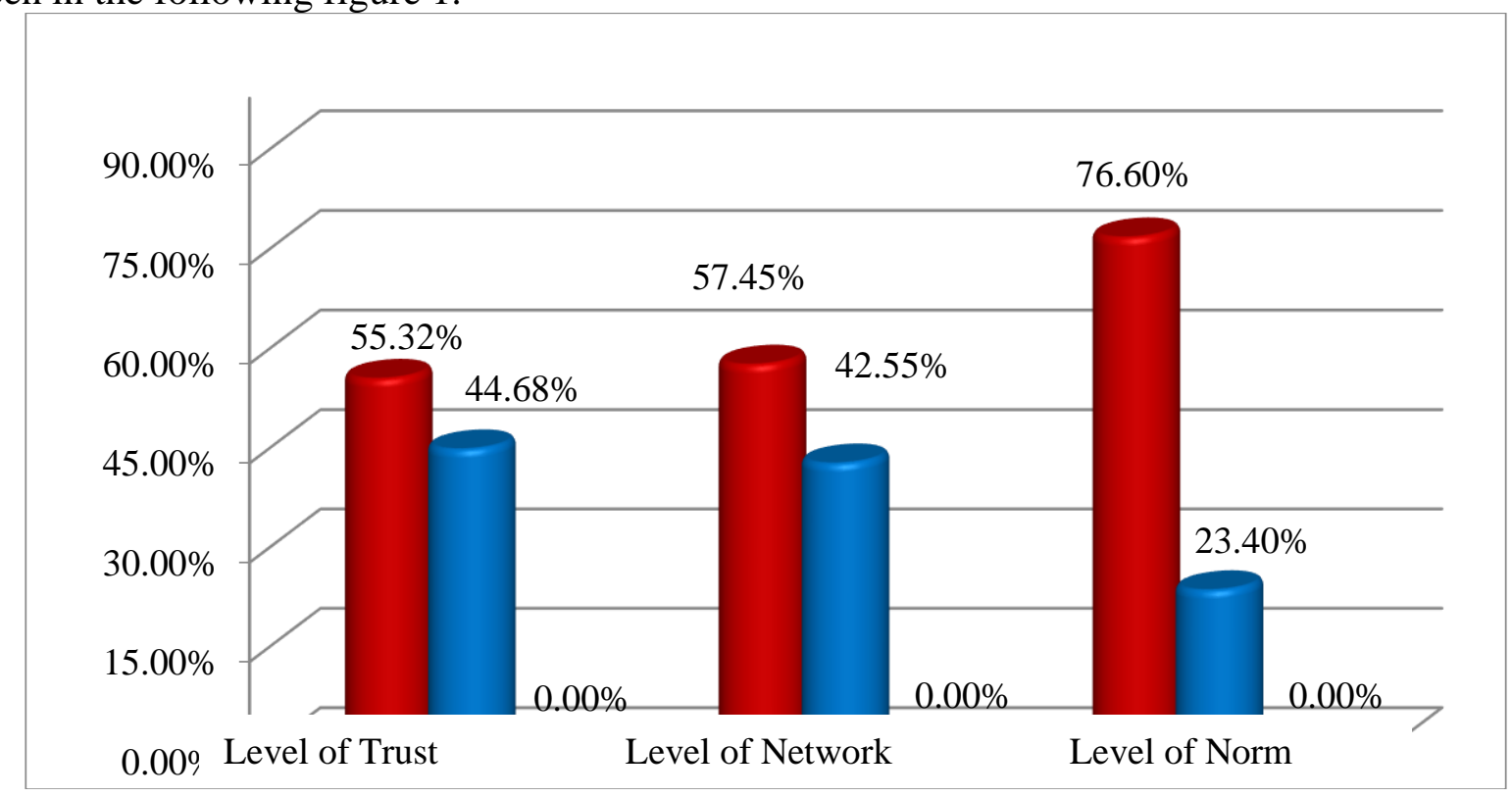

Figure 1: Comparison of Social Capital of Seaweed Cultivators in Liya Mawi Village

\subsection{Identification of Business Success Level}

The level of business success is focused on two criteria, namely sales volume and individual income level. The success of seaweed cultivation business in Liya Mawi Village is related to the purpose to be achieved. This is in accordance with the statement of Munajat (2007), he states that the success of the business as a condition or state company is able to achieve the desired objectives and able to show the condition or state of a better future There are several indicators that can be used to see the success of seaweed farming business. 


\subsection{Level of Selling}

Sales volume is the number of seaweed products that can be sold by seaweed farmers to buyers which is counted in one production period (two months). This sales volume can also affect the farmer' income. The higher sales volume in a single period of production the more income received by the seaweed farmer.

Classification of seaweed farmers based on sales volume can be seen in Table 4

Table 4: Seaweed Level of Selling in Liya Mawi Village

\begin{tabular}{|l|l|l|l|}
\hline \multirow{2}{*}{ Number } & \multirow{2}{*}{ Level of Selling } & \multicolumn{2}{|c|}{ Number of Cultivators } \\
\cline { 3 - 4 } & & Number (Sample) & Percentage (\%) \\
\hline 1 & Low $(<1666 \mathrm{~kg})$ & 8 & 17,02 \\
\hline 2 & Medium $(1667-2333 \mathrm{~kg})$ & 19 & 40,43 \\
\hline 3 & High $(>2334 \mathrm{~kg})$ & 20 & 42,55 \\
\hline Total & & 47 & 100,00 \\
\hline
\end{tabular}

Based on Table 4, most of the seaweed farmers have medium and high sales volume of $40.43 \%$ (19 persons) and $42.55 \%$ (20 persons) respectively, while those with more sales volume only $17.02 \%$ ( 8 people). Average sales volume of seaweed is $2161 \mathrm{~kg} /$ one time of production or as much as $1080.5 \mathrm{~kg} /$ month. The sales volume of seaweed is affected by the amount of seaweed production per period. No matter how the crops harvest that seaweed farmers get, all will be sold.

\subsection{Individual Income}

The individual income in this study is calculated based on the income generated from seaweed farming business compared to the regional minimum wage (RMW) per month. Provincial minimum wage according to BPS (2016) data of USD 134.06 for Southeast Sulawesi Province, PMW 2017 is set at USD 146.42. The classification of seaweed cultivation based on individual income in this study is presented in Table 5 below.

Table 5: Classification of Seaweed Cultivators by Income

\begin{tabular}{|l|l|l|l|}
\hline \multirow{2}{*}{ Number } & \multirow{2}{*}{$\begin{array}{l}\text { Income } \\
\text { (PMW = USD 146.42) }\end{array}$} & \multicolumn{2}{|c|}{ Number of Cultivators } \\
\cline { 3 - 4 } & Under PMW & 0 & 0 \\
\hline 1 & Above PMW & 47 & 100,00 \\
\hline 2 & & 47 & 100,00 \\
\hline
\end{tabular}

The data in Table 5 shows that all seaweed farmers have income above the PMW. Average of farmer's income is USD 455.16 / harvest. This means that seaweed cultivation has a favorable prospect. Social capital is a significant factor that determines the level of agricultural income (Wolz et al, 2005). Social and human capital affects income and that human capital has a greater effect on economic mobility than social capital (Weaver RD and Habibov N, 2012).

Business income is calculated from crop sales and then reduced by the costs incurred during the process of cultivation for one production period. The average of crops sales by seaweed farmers is 
USD 704.90, by the average of seaweed selling as many as $2.161 \mathrm{~kg}$. While the average cost incurred at a cultivation period is USD 249.73, which is calculated from the average cost of seeds, equipment, and labor. So that the average income of seaweed farmers in this study amounted to USD 455.16 for one crop ( 2 months) or USD 227.59 / month.

\section{Conclusions}

Based on the results and discussion, it can be concluded that: The social capital owned by seaweed farmers in Liya Mawi village are at medium to high category. Most farmers have moderate to high level of trust, medium to high social networks, and a high level of norm obedience.

With high social capital, a cultivator can easily expand his business from both the business scale and the cultivation technology he uses.

\section{References}

[1] Bourdieu, Pierre., 1986. The forms of capital. In: Jonh G. Richardson (ed) Handbook of Theory and Research for the Sociology of Education. Westport, CT: Greenwood Press.

[2] Coleman, JS., 1994. A rational choice perspective on economic sociology. In: Smelser, NJ and Swedberg, R. (eds) The Handbook of Economic Sociology. New York: Princeton University Press.

[3] Fausayana, I., Salman D., Ali SSA., Darma R., Sirajuddin N. 2015. Habitus of Etnic Bajo Bungin. American-Eurasian Journal of Sustainable Agriculture ISSN: 1995-0748 2015 Marchl 9(3): pages $1-9$.

[4] Fausayana I., Abdullah WG, Susanti F., Sidu D., Arimbawa P., Yunus L. 2017. Factors Affecting the Behavior of Farmers Toward the Risk of Seaweed Farming in the Bungin Permai village, southeast Sulawesi, Indonesia. AACL Bioflux, Vol 10(6): 1647-1653.

[5] Fukuyama, F. 2001. Sosial Capital, Civil Society, and development. Third Word Quarterly.

[6] Hansen BG and Greve A. 2015. The Role Of Human And Social Capital In Dairy Farming. Rural Society. Vol 24 (2) : 154-176

[7] Hoyman M., McCall J., Paarlberg L., Brennan J. 2016. Considering the Role of Social Capital for Economic Development Outcomes in U.S. Counties. Economic Development Quarterly. Vol 30 (4): $342-357$

[8] Limon JAG., Toscano EV., Fernandez FEG. 2014. Farmers' Contribution to Agricultural Social Capital: Evidence from Southern Spain. Rural Sociology. Vol 79 (3): 380 - 410.

[9] Lopez, A.F., Catarina, R.P., Tiago, N.S. 2012. When Sociable Workers Pay-Off: Can Firms Internalize sosial Capital Eksternalities. Structural Change and Economic Dynamics 23, 127-136

[10] Munajar, A. 2007.Hubungan Perilaku Kewirausahaan dengan Keberhasilan Usaha pada Pembudidaya Ikan Jaring Apung di Waduk Cirata Kabupaten Cianjur.Skripsi.FPIPS UPI Bandung.

[11] Putnam, R D. 1993. The Prosperous Community: Sosial Capital and Public Life. The American Prospect No. 13 Spring.

[12] Sharp JS and Smith MB. 2003. Social capital and farming at the rural-urban interface: the importance of nonfarmer and farmer relations. Agricultural Systems. Vol 76 (3) : 913 - 927

[13] Shideler DW and Kraybill DS. 2009. Social Capital: An Analysis of Factors Influencing Investment. The Journal of Socio Economic. Vol 38 (3): 443 - 455

[14] Ville ASS., Uli Locher GMH., Philip LE. 2016. Exploring the role of social capital in influencing knowledge flows and innovation in smallholder farming communities in the Caribbean. Vol 8 (3)।: $535-549$. 
[15] Weaver RD and Habibov N. 2012. Social Capital, Human Capital, and Economic Well-Being in the Knowledge Economy: Results from Canada's General Social Survey. Journal of Sociology \& Social Welfare. Vol 39 (2): 31 - 51.

[16] Wolz A., Fritzsch J., Reinsberg K. 2005. The Impact of Social Capital on Farm and Household Income: Results of a Survey among Individual Farmers in Poland. Paper prepared for presentation at the $94^{\text {th }}$ EAAE Seminar 'from households to firms with independent legal status: the spectrum of institutional units in the development of European agriculture, Ashford (UK), 9-10 April 2005. pp 1-13.

*Corresponding author.

E-mail address: inefausayana@ymail.com 